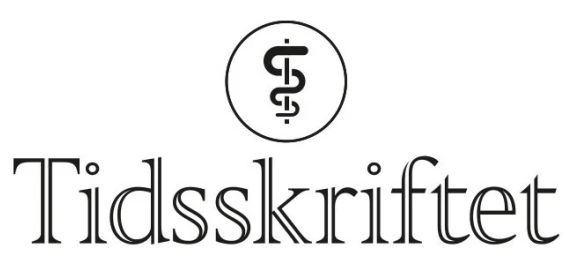

DEN NORSKE LEGEFORENING

\title{
Morsomt og lærerikt om penis
}

\author{
ANMELDELSER \\ VIKTOR BERGE \\ Urologisk avdeling \\ Oslo universitetssykehus, Radiumhospitalet
}

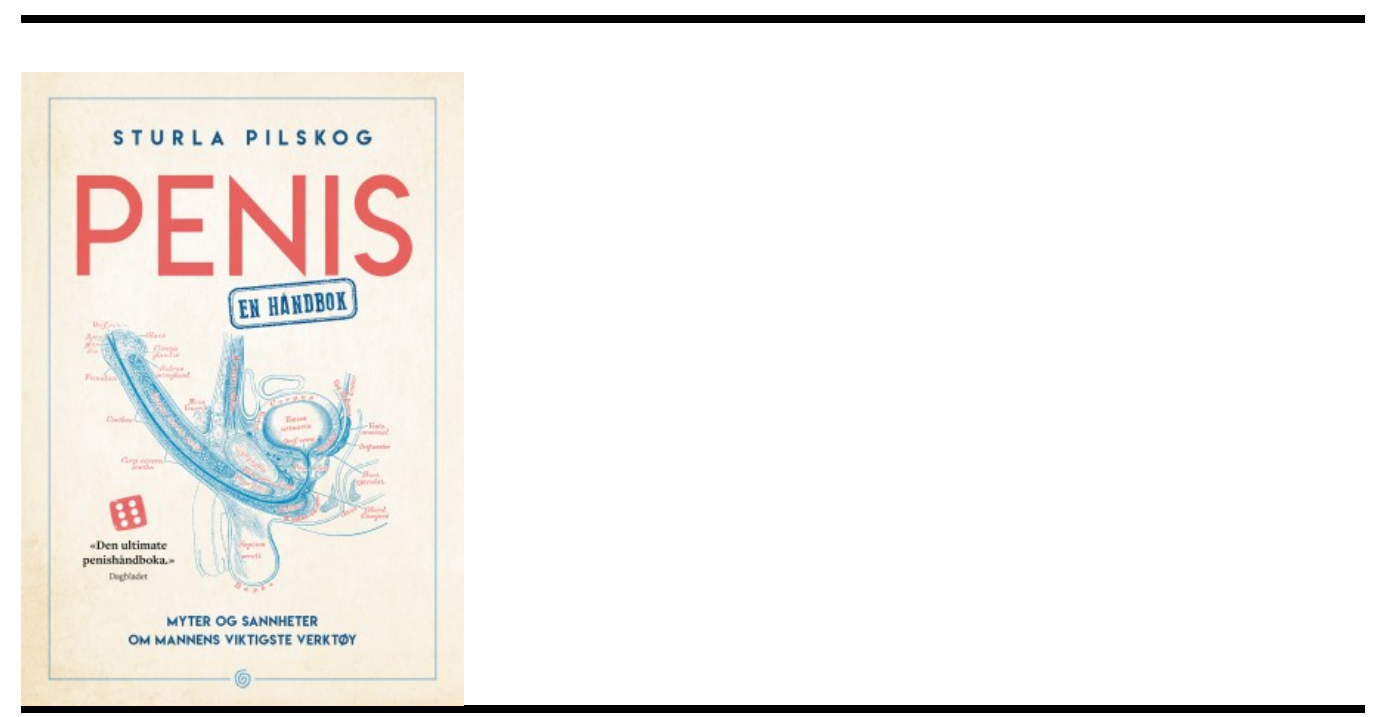

Sturla Pilskog

Penis. En håndbok

Myter og sannheter om mannens viktigste verktøy. 213 s, ill. Oslo: Kagge forlag, 2020. Pris NOK 399

ISBN 978-82-489-2534-7

I kjølvannet av opplysningsbøker om flere av kroppens organer måtte også denne boken komme. Den handler ikke bare om penis, men også skrotum, urinblæren, prostata og nyrene. Målgruppen er menn (særlig yngre), men også andre lesere kan ha stort utbytte av boka. Forfatterens uttalte hovedmål er å skille fakta fra feilinformasjon og ufarlige plager fra mer alvorlige symptomer. Dette lykkes han godt med.

Boka dekker mange temaer, på et lett og humoristisk språk. Den er delt inn i 14 kapitler med fengende titler, for eksempel «Av med luen?» om omskjæring og «Trang i hjelmen» om fimose. Innramming av fun facts gjør boka enda mer lettlest. 
Kildelisten fungerer stort sett bra. I kapittelet om penisstørrelse henvises det imidlertid til en britisk systematisk oversikt fra 2015 som omfatter over 15 ooo menn fra alle verdensdeler. Denne studien kunne ikke konkludere med forskjeller i gjennomsnittlig penisstørrelse blant menn i ulike folkegrupper og verdensdeler. På tross av dette hevder forfatteren i neste avsnitt at «... slike forskjeller finnes, det er det ingen tvil om» og beskriver en rangering av penisstørrelse blant ulike folkegrupper. Her savnes henvisning til relevante studier som understøtter påstanden.

Forfatteren framstiller ellers forskningsresultater på en lettfattelig måte, og mange, spesielt unge, vil finne svar på det de lurer på om penisstørrelse, seksuell debut og kjønnssykdommer, for å nevne noe. Boken krydres av mange kuriøse historiske anekdoter, for eksempel om penil pletysmografi (måling av volumendring) som ble brukt som løgndetektor for å «avsløre» rekrutter som påberopte seg homofili for å slippe unna militærtjeneste på 196o-tallet. Også behandling av impotens vies stor plass. Avsnittet «Lytt til penis, så unngår du hjerteinfarkt» kobler på en fin måte sammenhengen mellom erektil dysfunksjon og arteriosklerose.

Prostatakreft kalles «den 10. landeplage», en velplassert benevnelse tatt i betraktning det store antall menn som berøres av diagnostikk og behandling av denne sykdommen. Forfatteren bruker plass på å beskrive Gleason score-systemet i omtale av vevsundersøkelse ved prostatakreft, men burde heller ha trukket fram den mer moderne Gleason Grade Group-klassifiseringen, som er lettere å skjønne for lekfolk.

Boken dekker et behov der ute for kunnskap om mannens underliv og vil finne sin naturlige plass blant de andre populærvitenskapelige bøkene om kroppen.

Publisert: 4. mai 2020. Tidsskr Nor Legeforen. DOI: 10.4045/tidsskr.20.0234

(C) Tidsskrift for Den norske legeforening 2023. Lastet ned fra tidsskriftet.no 26. april 2023. 